\title{
PERSEPSI MAHASISWA TERHADAP PENDIDIKAN MORAL SISWA
}

\author{
Prihma Sinta Utami \\ Program Studi Pendidikan Pancasila dan Kewarganegaraan Universitas Muhammadiyah Ponorogo \\ Jl. Budi Utomo, No.10 Ponorogo \\ email: prihmasinta@gmail.com
}

\begin{abstract}
Referring to the national educational objectives that the subjects of PPKn (Civic and Pancasila Education) prepare students to be good citizens. Moral education is one element in the study of subject areas of PPKn that must be given to the students as a guide in plunging in the community. Students of PPKn study program are prepared as prospective educators who are able to integrate various aspects of citizenship problems and social problems. Not separated from the role of students in the program of PPKn, it is necessary understanding for each student in knowing the extent of moral education role for students. The purpose of this study is to understand and to know the perception of PPKn's student Faculty of Education University Muhammadiyah of Ponorogo to moral education students in Ponorogo regency. The research method used in this research is descriptive qualitative. It can be concluded that student perception about moral education consisting of three main aspects of moral education of students related to morality of God, morals to fellow human beings, and morals to the environment indicates that for morale students of God and fellow human beings are said to have good enough and moral education Has been done as it should. As for the moral education of students related to morals to the environment indicates that it is still at a level that is less and needs to be improved again, especially for some related parties.
\end{abstract}

Keywords: adjektiva education

\begin{abstract}
Abstrak: Mengacu pada tujuan pendidikan nasional bahwasannya mata pelajaran PPKn mempersiapkan siswa untuk menjadi warga negara yang baik. Pendidikan moral merupakan salah satu elemen dalam kajian bidang mata pelajaran PPKn yang wajib diberikan kepada siswa sebagai pedoman dalam terjun di masyarakat.Mahasiswa prodi PPKn dipersiapkan sebagai calon pendidik yang mampu mengintegrasikan berbagai aspek dalam permasalahan kewarganegaraan maupun permasalahan sosial.Tidak lepas dari peran mahasiswa prodi PPKn tersebut, maka diperlukan pemahaman bagi setiap mahasiswa dalam mengetahui sejauh mana peran pendidikan moral bagi siswa.Tujuan penelitian ini adalah untuk memahami dan mengetahui persepsi mahasiswa Prodi PPKn FKIP Universitas Muhammadiyah Ponorogo terhadap pendidikan moral siswa di Kabupaten Ponorogo.Metode penelitian yang digunakan dalam penelitian ini adalah deskriptif kualitatif. Dapat disimpulkan bahwa persepsi mahasiswa tentang pendidikan moral yang terdiri dari tiga aspek utama yaitu pendidikan moral siswa terkait akhlak terhadap Tuhan YME, akhlak terhadap sesama manusia, dan akhlak terhadap lingkungan menunjukkan bahwa untuk moral siswa terhadap Tuhan dan sesama manusia dikatakan sudah cukup baik dan pendidikan moral sudah terlaksana sebagaimana mestinya. Sedangkan untuk pendidikan moral siswa terkait akhlak terhadap lingkungan menunjukkan bahwa masih berada pada taraf yang kurang dan perlu untuk ditingkatkan lagi khususnya bagi beberapa pihak yang terkait.
\end{abstract}

Kata kunci: pendidikan moral

Dunia remaja dapat dikatakan sebagai dunia dimana seseorang mulai mencari jati dirinya masing-masing.Pada masa ini merupakan masa yang rentan dengan adanya berbagai pengaruh baik yang datang dari dalam maupun dari luar lingkungan remaja itu sendiri.Fenomena-fenomena yang sering terjadi banyak menunjukkan bagaimana sisi kedewasaan remaja yang masih premature dan belum menemukan jati dirinya secara utuh.Banyaknya kejadian-kejadian yang 
mengarah pada tindak kekerasan maupun penyimpangan pada kalangan remaja saat ini mengindikasikan lemahnya nilai moral pada diri remaja.

Moral siswa yang notabenenya adalah seorang remaja juga dapat dikatakan semakin menurun.Hal tersebut sangat memprihatikan karena mengindikasikan bahwa moral pendidikan saat ini sedang berada pada taraf yang lemah. Dunia pendidikan saat ini sedang mengkaji serta selalu melakukan refleksi kembali untuk dapat mengintegrasikan muatan nilai moral atau nilai karakter sebagai pedoman bagi siswa maupun remaja.Sekolah dapat dikatakan sebagai wadah atau agen dalam menjembatani terwujudnya tujuan pendidikan nasional serta tujuan dari masyarakat secara umum.Berdasarkan hal tersebut maka konteks mata pelajaran PPKn sesungguhnya tidak hanya berorientasi pada pemberian pengetahuan namun juga memberikan pemahaman terhadap nilai-nilai moral (Belakang \& Esa, 2013).

Melihat kondisi diatas pendidikan hendaknya berfokus pada pendidikan yang mengarahkan tentang perbaikan moral siswa. Zuriah (2007: 19) mengungkapkan bahwa pendidikan moral lebih banyak membahas tentang masalah dilema dalam masyarakat yang berguna untuk mengambil keputusan moral yang terbaik bagi diri dan masyarakatnya. Dapat disimpulkan bahwa pendidikan moral bukan lagi membahas tentang hal yang baik dan yang buruk, namun lebih pada penerapannya dalam mengambil keputusan dan sesuai dengan kehendak masyarakat. Salah satu cara yang dilakukan oleh pihak sekolah yaitu dengan menyelipkan nilai pendidikan moral atau karakter dalam komponen pembelajaran seharihari. Hal ini juga sejalan dengan kurikulum prodi PPKn FKIP Universitas Muhammadiyah Ponorogo yang memberikan muatan mata kuliah teori pendidikan moral bagi mahasiswa.

Pendidikan moral siswa pada dasarnya tidak hanya membahas tentang perilaku siswa seharihari saja. Ada tiga komponen utama dalam pengembangan pendidikan moral bagi siswa, antara lain akhlak terhadap Tuhan YME, akhlak terhadap sesama dan akhlak terhadap lingkungan.Keselarasan dalam pelaksanaan tiga komponen dasar dalam pengembangan pendidikan moral tersebut dapat digunakan sebagai fondasi pembentukan moral siswa yang baik.

Tiga komponen pendidikan moral di atas apabila dijabarkan dalam pengertian yang lebih luas dapat diartikan sebagai berikut: (1) akhlak terhadap Tuhan Yang Maha Esa dapat berwujud siswa sudah mengenal siapa Tuhannya. Setelah siswa mengenal siapa Tuhannya selanjutnya diharapkan siswa melewati fase memahami bagaimana hubungan antara manusia kepada Tuhan melalui tata cara beribadah. Tahap selanjutnya siswa dapat memahami bahwa tempat meminta pertolongan itu hanya kepada Tuhan; (2) akhlak terhadap sesama manusia dapat berwujud siswa harus memahami bahwa setiap manusia mempunyai jati diri dan mampu memahami dimana posisi dirinya. Setelah siswa memahami hal tersebut, siswa mampu memposisikan diri bahwa mereka ada karena adanya orang tua sehingga orang tua merupakan orang yang harus dihormati dan dihargai. Tahap selanjutnya adalah siswa dapat menghargai, menghormati dan memahami keberadaannya diantara orang yang lebih tua, orang yang lebih muda dan memahami posisi mereka terhadap sesama; (3) akhlak terhadap lingkungan dapat berwujud bahwa siswa dapat menghargai keberadaan alam sekitar baik dalam wujud flora dan fauna. Selanjutnya siswa mampu memahami keberadaannya sebagai makhluk sosial masyarakat yang berarti bahwa mereka tidak dapat hidup tanpa adanya orang lain.

Persepsi terdiri dari beberapa prinsip dasar antara lain: (a) bersifat relatif bukan absolut, (b) selektif, (c) mempunyai tatanan, (d) dipengaruhi oleh kesiapan dan harapan, dan (e) persepsi sekelompok orang akan berbeda dengan persepsi kelompok lain meskipun dalam situasi yang sama (Widiastuti \& Taat, 2013). Melihat pengertian tersebut dapat disimpulkan bahwa pemahaman tentang persepsi tersebut dapat berbeda-beda. Pemahaman seseorang akan sesuatu objek dapat menghasilkan pemahaman yang berbeda-beda sesuai sudut pandang mereka masing-masing. Dalam tulisan ini akan dipaparkan tentang persepsi mahasiswa prodi PPKn FKIP Universitas Muhammadiyah Ponorogo terhadap pendidikan moral siswa kabupaten Ponorogo.

Persepsi merupakan proses yang melibatkan aspek kognitif dan afektif individu untuk melakukan pemilihan, pengaturan, dan pemahaman serta penginterpretasian rangsang-rangsang indrawi menjadi suatu gambar obyek tertentu secara utuh. Persepsi juga dapat dikatakan sebagai proses mengetahui atau mengenali objek dan kejadian objektif dengan bantuan indra (Danta \& Ginting, 2003: 6). 
Faktor-faktor yang mempengaruhi persepsi menurut Baltus (Danta \& Ginting, 2003: 6-7) adalah : (a) kemampuan dan keterbatasan fisik dari alat indera dapat mempengaruhi persepsi untuk sementara waktu ataupun permanen, (b) kondisi lingkungan, (c) pengalaman masa lalu. Bagaimana cara individu untuk menginterpretasikan atau bereaksi terhadap suatu stimulus tergantung dari pengalaman masa lalunya, (d) kebutuhan dan keinginan. Ketika seorang individu membutuhkan atau menginginkan sesuatu maka ia akan terus berfokus pada hal yang dibutuhkan dan diinginkannya tersebut, (e) kepercayan, prasangka dan nilai. Individu akan lebih memperhatikan dan menerima orang lain yang memiliki kepercayaan dan nilai yang sama dengannya. Sedangkan prasangka dapat menimbulkan bias dalam mempersepsi sesuatu.

Ada beberapa tahap dalam persepsi, menurut Walgito (Anshari, 2013: 11-12 ) adapun tahapan dalam persepsi sebagai berikut: (1) tahap pertama, merupakan tahap kealaman atau proses fisik yaitu penangkapan stimulus oleh indera manusia, (2) tahap kedua, merupakan tahap fisiologis yaitu yaitu tahap dimana proses diteruskannya stimulus yang diterima oleh reseptor, (3) tahap ketiga, merupakan tahap psikologik merupakan proses timbulnya kesadaran individu tentang stimulus yang diterima reseptor, dan (4) tahap keempat, merupakan hasil dari proses persepsi yaitu berupa tanggapan dan perilaku.

Pendidikan karakter, pendidikan budi pekerti dan pendidikan moral terkadang menjadi bahasan yang dianggap sama. Pada dasarnya pendidikan moral lebih membahas pada masalah tindakan seseorang yang berdasarkan pada nilai dan kehidupan nyata.Pendidikan moral lebih banyak mengedepankan pada realitas fenomena yang ada lalu mengkaji serta mengambil keputusan yang terbaik (Utami, 2016:3).

Pendidikan moral lebih banyak membahas tentang masalah dilema dalam masyarakat yang berguna untuk mengambil keputusan moral yang terbaik bagi diri dan masyarakatnya.Dapat disimpulkan bahwa pendidikan moral bukan lagi membahas tentang hal yang baik dan yang buruk, namun lebih pada penerapannya dalam mengambil keputusan dan sesuai dengan kehendak masyarakat (Zuriah, 2007:107).

Ruang lingkup pendidikan moral pada dasarnya tidak hanya terbatas pada nilai-nilai perilaku sehari-hari saja.Ada tiga hal mendasar pada substansi pendidikan moral itu sendiri, diantaranya yaitu akhlak terhadap Tuhan Yang Maha Esa, akhlak terhadap sesama manusia, dan akhlak terhadap lingkungan.Ketiga ruang lingkup ini sebenarnya menjadi fondasi dalam mewujudkan para siswa memiliki moral yang baik.

Tiga komponen pendidikan moral di atas apabila dijabarkan dalam pengertian yang lebih luas dapat diartikan sebagai berikut: (a) akhlak terhadap Tuhan yang Maha Esa dapat berwujud siswa sudah mengenal siapa Tuhannya. Setelah siswa mengenal siapa Tuhannya selanjutnya diharapkan siswa melewati fase memahami bagaimana hubungan antara manusia kepada Tuhan melalui tata cara beribadah. Tahap selanjutnya siswa dapat memahami bahwa tempat meminta pertolongan itu hanya kepada Tuhan; (b) akhlak terhadap sesama manusia dapat berwujud siswa harus memahami bahwa setiap manusia mempunyai jati diri dan mampu memahami dimana posisi dirinya.Setelah siswa memahami hal tersebut, siswa mampu memposisikan diri bahwa mereka ada karena adanya orang tua sehingga orang tua merupakan orang yang harus dihormati dan dihargai. Tahap selanjutnya adalah siswa dapat menghargai, menghormati dan memahami keberadaannya diantara orang yang lebih tua, orang yang lebih muda dan memahami posisi mereka terhadap sesama; (c) akhlak terhadap lingkungan dapat berwujud bahwa siswa dapat menghargai keberadaan alam sekitar baik dalam wujud flora dan fauna. Selanjutnya siswa mampu memahami keberadaannya sebagai makhluk sosial masyarakat yang berarti bahwa mereka tidak dapat hidup tanpa adanya orang lain (Utami, 2016:4).

Beberapa hal di atas dikatakan sebagai komponen utama dalam pengembangan pendidikan moral di pendidikan formal. Selanjutnya akan muncul jabaran-jabaran nilai pada setiap tiga komponen yang disebutkan di atas. Nilai-nilai moral sebagai jabaran tiga komponen utama moral tersebut diantaranya meyakini adanya Tuhan Yang Maha Esa, menaati ajaran agama, memiliki dan mengembangkan toleransi, memiliki rasa menghargai diri sendiri, tumbuhnya disiplin diri, mengembangkan etos kerja dan belajar, memiliki rasa tanggung jawab, mampu berfikir positif, memiliki kebersamaan dan gotong-royong, dan lainlain.

Pendidikan moral harus disipkan serta direncanakan secara matang oleh para stakehold- 
ers sebagai think-tank, baik para pakar pendidikan moral seperti para rohaniawan (tokoh agama), tokoh masyarakat seperti kepala sekolah, guru maupun orang tua murid. Keberhasilan pelaksanaan pendidikan moral adalah mampu menghasilkan siswa yang memiliki kompetensi personal dan kompetensi sosial yang memiliki moral dan dinamis sehingga menghasilan warga negara yang baik (good citizen) (Dwi Kushrahmadi, 2007:124).

Dewasa ini pengaruh diluar guru dan orang tua sangatlah cepat sampai pada pola perilaku siswa.Banyak hal di luar kendali guru ataupun orang tua yang tidak disadari sudah mulai terbawa pada pengaruh dunia globalisiasi dan perkembangan IT yang begitu cepat. Guru apabila tidak bisa mengikuti pola perkembangan siswa saat ini akan berdampak perilaku siswa yang kurang antusias terhadap guru.

Prinsip pembelajaran moral harus menempatkan siswa sebagai pelaku moral yang das sollen, mereka harus diberi kesempatan untuk dapat belajar secara aktif baik fisik maupun mental. Maksud dari aktif secara mental berarti bahwa siswa berfikir dengan menggunakan pengetahuannya untuk mempersepsikan pengalaman yang baru disamping secara fisik dapat diamati keterlibatannya dalam belajar sehingga nilai moral menjadi bagian dari hidupnya (Dwi Kushrahmadi, 2007:127).

Menurut Udin S. Winataputra (Purwanti, 2016:2) Pendidikan Kewarganegaraan (PKn) merupakan mata pelajaran yang memiliki salah satu misinya sebagai pendidikan nilai. Dalam proses pendidikan nasional PKn pada dasarnya merupakan wahana pedagogis pembangunan watak atau karakter. Secara makro PKn juga merupakan wahana sosial-pedagogis pencerdasan kehidupan bangsa.Hal ini sejalan dengan konsepsi fungsi pendidikan nasional membentuk watak serta peradaban bangsa yang bermartabat dalam rangka mencerdaskan kehidupan bangsa.

\section{METODE}

Metode yang digunakan dalam pengkajian ini adalah deskriptif kualitatifdengan mengkaji penerapan pendidikan moral di sekolah dan mengetahui persepsi mahasiswa PPKn terkait pendidikan moral siswa di Kabupaten Ponorogo. Tepatnya di prodi PPKn FKIP Universitas Muhammdiyah Ponorogo, sebab diyakini bahwa mahasiswa Prodi PPKn merupakan prodi yang menyiapkan calon pendidik yang mampu menerapkan pendidikan moral.Adapun subjek kajian ini adalah seluruh mahasiswa Prodi PPKn semester III Fakultas Keguruan dan Ilmu Pendidikan Universitas Muhammadiyah Ponorogo. Teknik analisis data dalam kajian ini akan dilakukan melalui 3 tahap dengan cara menggolongkan, mereduksi dan menghilangkan data yang tidak sesuai dengan kemudian dipaparkan secara deskriptif. Tahap selanjutnya yaitu proses membuat kesimpulan sesuai dengan tujuan kajian.

\section{HASIL DAN PEMBAHASAN}

Berdasarkan hasil wawancara dan observasi di lapangan ditemui beberapa hasil analisis yang menunjukkan bagaimana persepsi mahasiswa terkait pendidikan moral siswa di kabupaten Ponorogo.Informan adalah mahasiswa yang sudah melaksanakan kegiatan magang di beberapa sekolah di Kabupaten Ponorogo baik yang berstatus swasta maupun negeri.

Temuan hasil dihubungkan dengan kajian teori tentang pendidikan moral.Adapun tiga kajian yang dibahas yaitu pendidikan moral siswa terkait tentang akhlak terhadap Tuhan YME, pendidikan moral terkait akhlak terhadap sesama manusia dan terkait akhlak terhadap lingkungan.

Seperti yang telah dibahas dalam kajian teori bahwasannya pendidikan moral berguna untuk mengambil keputusan moral bagi dirinya sendiri sebelum berlanjut kepada masyarakat.Bagi diri sendiri kaitannya dengan hubungan terhadap Tuhan YME merupakan salah satu hal mendasar untuk mengarahkan kemana arah moral seseorang dalam menjalani kehidupan sehari-hari. Pemahaman yang mendasar terkait akhlak terhadap Tuhan YME yang pertama adalah siswa telah mengenal siapa Tuhannya.Setelah siswa mampu mengenali Tuhannya selanjutnya siswa diharapkan mampu memahami bagaimana hubungan manusia kepada Tuhan melalui tata cara ibadah. Tahap terakhir siswa dapat memahami bahwa tempat meminta pertolongan hanya kepada Tuhan.

Siswa mengenal siapa Tuhannya melalui perwujudannya saat memasuki sholat lima waktu para siswa sudah menyadari kewajibannya dan pergi ke masjid untuk melaksanakan sholat berjamaah dan siswa berdoa sebelum dan 
sesuadah melaksanakan pembelajaran. Untuk melihat bagaimana siswa sudah menerapkan bahwa tempat meminta pertolongan hanya kepada Tuhan, dapat diketahui dari aktivitas siswa yang selalu mendengarkan adzan dan menyebut nama Tuhan ketika sedang terkena musibah dan kesedihan, ketika ada siswa yang berbohong dengan temannya siswa tersebut akan mengucapkan kata bahwa takut dosa.

Dari aktivitas siswa di atas, secara garis besar siswa-siswa sudah mengenal Tuhannya dengan cara mereka masing-masing. Pemahaman tentang siapa Tuhannya sudah diwujudkan dalam kehidupan mereka sehari-hari.Cara siswa mewujudkan pemahaman terhadap Tuhannya tersebut diwujudkan dalam tindakan ibadah seharihari, selain itu juga dapat dilihat dalam tindakan yang menyertakan Tuhan atau mengingat Tuhan dalam tindakannya.

Pendidikan moral berikutnya terkait tentang akhlak terhadap sesama manusia.Setiap manusia harus memahami tentang jati dirinya dan dimana posisinya berada. Hal ini sama dengan yang harus dilakukan siswa bahwasannya mereka harus memahami keberadaan dirinya dalam lingkungannya. Tahap selanjutnya adalah siswa dapat menghargai, menghormati dan memahami keberadaannya diantara orang yang lebih tua, orang yang lebih muda dan memahami posisi mereka terhadap sesama. Siswa sudah mampu menjalin hubungan dengan teman yang berbeda agama, terlihat ketika siswa Islam melakukan sholat berjamaah, siswa yang Kristen menunggu sampai teman yang lain selesai sholat dan mereka akan pulang bersama-sama. Siswa dengan teman yang berbeda agama tidak membeda-bedakan satu dengan yang lainnya, para siswa saling menyapa dan menjunjung tinggi toleransi.

Terkait dengan sikap siswa kepada orang lain terlebih kepada orang yang lebih tua, dapat mencerminkan bagaimana mereka memahami posisi mereka dalam beberapa lingkungan. Siswa memperhatikan penampilannya disaat berinteraksi dengan guru, penampilan tersebut terlihat dalam berperilaku sopan dan menaati aturan yang diberikan oleh guru. Mereka sudah memahami posisinya sebagai siswa di depan guru-guru atau orang yang lebih tua, selain itu mereka bisa menghargai pendapat teman yang lainnya di dalam kelas.Ada beberapa siswa yang belum memahami posisinya di kelas misalnya ketika guru sedang menjelaskan di depan kelas, siswa banyak yang celotehan di belakang dan tidak memerhatikan guru. Namun, ketika diluar kelas mereka sudah sangat menghargai gurunya dengan berjabat tangan kepada guru dan karyawan ketika siswa datang di sekolah.

Dari beberapa pendapat informan di atas dapat ditarik kesimpulan bahwa sebagian besar siswa sudah memahami dimana posisi mereka berada dalam hubungannya dengan sesama manusia.Pada kajian ini difokuskan pada hubungan dengan teman sebaya dan kepada orang yang lebih tua di sekolah yaitu guru dan karyawan. Meskipun ada yang beranggapan bahwa masih ada siswa yang belum memahami posisinya di dalam kelas, namun secara keseluruhan siswa dikatakan sudah mampu menghargai orang lain sesuai dengan keberadaannya.

Pendidikan moral yang ketiga yaitu hubungannya terkait dengan akhlak terhadap lingkungan.Setiap makhluk harus saling mencintai satu dengan yang lainnya, terlebih manusia seyogyanya dapat mencintai keberadaan alam sekitar yang berwujud flora ataupun fauna. Ketika seseorang mempunyai moral yang baik dan bijak akan selalu memperhatikan kondisi alam sekitarnya. Hati nurani seseorang yang akan membawa orang tersebut akan memperhatikan lingkungan sekitarnya. Setelah pemahaman akan lingkungan terbentuk secara tidak langsung seseorang akan merasakan bahwa dirinya adalah makhluk sosial yang tidak dapat lepas dari orang lain. Pada dasarnya siswa memahami lingkungannya, terlebih sekolah mengadakan kegiatan Jumat bersih untuk merealisasikan sekolah adiwiyata. Siswa sudah memahami lingkungan skeitarnya dengan menyiram bunga setiap pagi sesuai dengan jadwal piket yang sudah dibentuk.

Beberapa informan tidak pernah melihat siswa memperhatikan lingkungannya, yang saya lihat karena sudah ada tukang kebun yang selalu merawat lingkungan di sekitar sekolah. Siswa cenderung acuh terhadap lingkungan, karena menurut mereka tugas merawat tanaman dan lingkungan itu adalah tugas pegawai kebersihan. Siswa tidak pernah memperhatikan lingkungan di sekitarnya kecuali ada agenda dari sekolah untuk melakukan kegiatan kebersihan bersama, mereka menganggap karena sudah ada tukang kebersihan yang bertugas membersihkan sekolah.

Berdasarkan hasil wawancara beberapa informan dapat ditarik kesimpulan bahwa masih banyak dijumpai di lapangan bahwasannya 
pendidikan moral siswa terhadap kepeduliannya terhadap lingkungan masih dianggap rendah.Hal ini dilihat dari anggapan mereka yang belum mempunyai kesadaran untuk memperhatikan lingkungannya dan lebih mengandalkan pada petugas kebersihan sekolah untuk melakukan tugas tersebut.

\section{SIMPULAN}

1. Persepsi mahasiswa terkait pendidikan moral siswa di Kabupaten Ponorogo terkait akhlak terhadap Tuhan YME secara garis besar mengatakan bahwa moral siswa terkait hal tersebut sudah cukup baik. Rata-rata siswa sudah memahami siapa Tuhannya, selanjutnya mereka mampu merealisasikannya dalam wujud ibadah dan berusaha menyertakan Tuhan dalam setiap tindakan mereka.

2. Persepsi mahasiswa terkait pendidikan moral siswa di kabupaten Ponorogo terkait akhlak terhadap sesama manusia mengatakan bahwa moral siswa terkait hal tersebut sudah berjalan

\section{DAFTAR RUJUKAN}

Belakang, A. L., \& Esa, Y. M. (2013). Peran Guru PKn terhadap Pembentukan Moral Siswa di SMP Negeri 10 Palu, (April).

Danta, E. K. A., \& Ginting, J. (2003). Hubungan Persepsi Terhadap Progam Pengembangan Karir dengan Kompentensi Kerja. Digitized by USU Digital Library, 2-3.

Dwi Kushrahmadi, S. (2007). Pentingnya Pendidikan Moral Bagi Anak Sekolah Dasar. Dinamika Pendidikan, 14(1), 118130.

Moleong, Lexy J. 2007. Metodologi Penelitian Kualitatif. Bandung: PT. Remaja Rosdakarya cukup baik. Hubungan siswa dengan teman sebaya khususnya dengan yang berbeda agama dikatakan dapat saling menjaga toleransi satu dengan yang lainnya. Hubungannya dengan orang yang lebih tua atau dengan guru dan karyawan secara garis besar rasa menghargai dan menghormati sudah diterapkan oleh siswa.

3. Persepsi mahasiswa terkait pendidikan moral siswa di kabupaten Ponorogo terkait akhlak terhadap lingkungan dikatakan masih cukup kurang. Menurut persepsi mahasiswa bahwasannya moral siswa terhadap lingkungan masih kurang karena masih rerata secara siswa masih acuh dnegan kondisi lingkungan sekitarnya. Sebagian besar siswa masih mengandalkan petugas kebersihan atau tukang kebun untuk mengurus lingkungan sekitar sekolah mereka. Hal ini yang seharusnya menjadi perhatian oleh beberapa pihak khususnya pihak skeolah untuk lebih membiasakan siswa mencintai lingkungan sekitar mereka.

Utami, P. S. (2016). Integrasi Pendidikan Moral Dalam Pembelajaran PPKn Melalui Media Project Citizen. Prosiding Konferensi Nasional Kewarganegaraan II.

Widiastuti, A., \& Taat, D. A. N. (2013). Persepsi dan Sikap Mahasiswa Terhadap Pendidikan Karakter di Prodi Pendidikan IPS UNY, 10(2).

Zuriah, N. (2007). Pendidikan Moral\& Budi Pekerti Dalam Perspektif Perubahan. Jakarta: Bumi Aksara. 